\title{
An evaluation of the systematics of the genus Thalia (Thaliacea, Salpidae) based on new material from the EASTROPAC and MORO expeditions
}

\author{
María C. Daponte', Roberto J. Castro² \& Graciela B. Esnal ${ }^{1}$ \\ ${ }^{1}$ Departamento de Ciencias Biológicas, Facultad de Ciencias Exactas y Naturales, Universidad de Buenos \\ Aires, 1428 Buenos Aires, Argentina; ${ }^{2}$ Facultad de Ingenieria, Universidad de Flores, 1406 Buenos Aires, \\ Argentina
}

Keywords: Tunicata, Salpidae, Thalia, Thalia democratica group

\begin{abstract}
Until 1973, when Van Soest revised Thalia Blumenbach, 1798, this genus comprised only two species: Thalia democratica (Forsskål, 1775) and Thalia longicauda (Quoy \& Gaimard, 1824). The former showed great variability, which led Van Soest to distinguish five species: $T$. democratica, $T$. orientalis, $T$. rhomboides, $T$. cicar, and $T$. sibogae. Some authors have ignored this revision considering the observed differences of infraspecific level. In the present work new material is studied analysing variables not previously considered, such as the development of blastogenic stolons in the solitary zooids and the location of the tunnel opening through which the bud blocks are liberated. These characters previously permitted a separation of closely related species in the genus Ihlea. The results show that stolon features, even though they permit a separation of solitary zooids of Thalia longicauda, do not discriminate all species of the " $T$. democratica group" since they are only useful in distinguishing $T$. democratica from $T$. sibogae. Other variables, mainly qualitative, do permit differentiation. The sympatric distribution of these taxa supports Van Soest's hypothesis as well.
\end{abstract}

\section{Resumen}

Hasta 1973, cuando Van Soest revisó el género Thalia Blumenbach 1798, éste comprendía sólo dos especies: Thalia democratica (Forsskål, 1775) y Thalia longicauda (Quoy \& Gaimard, 1824). La primera presentaba gran variabilidad, lo que condujo a la separación en cinco especies: $T$. democratica, $T$. orientalis, $T$. rhomboides, $T$. cicar y $T$. sibogae. Algunos autores desconocieron esta revisión considerando que las diferencias serían de nivel infraespecífico. En este trabajo se estudia nuevo material y analizan otras variables que no fueron consideradas con anterioridad, tales como el desarrollo del estolón blastogenético en los oozooides y la localización de la abertura del túnel de salida de los brotes, caracteres que permitieron separar especies estrechamente emparentadas en el género Ihlea. Los resultados muestran que las diferencias del estolón permiten separar los oozooides de Thalia longicauda de los del resto de las especies del género, pero no discriminan entre las especies del "grupo Thalia democratica", ya que solo permiten distinguir $T$. democratica de $T$. sibogae. Otras variables, principalmente cualitativas, permiten la diferenciación. Se suma en apoyo de la hipótesis de Van Soest el patrón de distribución simpátrica de estos taxones.

\section{Introduction}

Until 1973, when Van Soest revised Thalia Blumenbach, 1798, the genus comprised only two species readily distinguishable by their solitary or by their aggregate zooids: $T$. democratica (Forsskål, 1775) and T. longicauda (Quoy \& Gaimard, 1824). However, the former showed great variability. Tokioka (1937) described a variety from Japanese waters that he named orientalis and a form of this variety: echinata. Borgelt (1968 a \& b) described three subspecies in spite of their sympatric occurrence in Japanese and South African waters: $T$. democratica democratica (= Tokioka's typical variety); $T$. $d$. orientalis (= partly Tokioka's variety orientalis including its form echinata), and $T$. $d$. intermedia (= also partly Tokioka's variety orientalis including its form echinata). Van Soest (1973) considered these three subspecies full species: $T$. democratica (Forsskål, 1775), T. orientalis Tokioka, 1937; and for the latter he reinstated $T$. rhomboides (Quoy \& Gaimard, 1824). In addition he described two new species, $T$. cicar and $T$. sibogae, and later (Van Soest, 1975a) he described another new species, $T$. rhinoceros. Solitary zooids of these species can, in general, be readily recognized but aggregate zooids of $T$. democratica, $T$. cicar, and $T$. orientalis 
cannot at present be separated on morphological characters.

Braconnot (1973) rejected this revision, considering the observed differences significant only at an infraspecific level.

Dauby \& Godeaux (1987) used the same characters considered by Van Soest (1973) in the solitary zooids (size, aspect of the body muscles, number of muscle fibers, shape of the atrial palps and posterior and medioventral projections, presence of lateral projections and echinations) to calculate euclidean distances in the multidimensional plane of the variables, and ratified Van Soest's proposal.

The aim of the present work is to contribute to a further increase in knowledge of Thalia species with the analysis of new material and to incorporate other variables not previously considered, such as reproductive features like the development of the blastogenic stolon in the solitary zooids and of the embryo in the aggregate zooids. These characters previously permitted a separation of closely related species in the genus Ihlea: I. racovitzai (Van Beneden, 1913) and I. magalhanica (Apstein, 1894) (cf. Esnal \& Daponte, 1990; Daponte \& Esnal, 1994).

\section{Material and methods}

A total of 147 plankton samples were studied. They were collected during the EASTROPAC and MORO expeditions and kindly provided by the Smithsonian Oceanographic Sorting Center, Washington. The samples from the EASTROPAC expedition were collected during the period from January 1967 to April 1968 in the area between $20^{\circ} \mathrm{N}$ and $20^{\circ} \mathrm{S}$ and between $119^{\circ} \mathrm{W}$ and the west coast of the American Continent. They came from $200-0 \mathrm{~m}$ depth. Open nets, $50 \mathrm{~cm}$ in diameter, 300 $\mu \mathrm{m}$ mesh size were used. During the MORO expedition, which took place in the Arafura, Coral, Celebes, Solomon and Moluccas seas and off the New Guinea coast in 1979, most samples were collected from a small skiff launched from the research vessel Alpha Helix (Scripps Institution of Oceanography). They were taken with open conical nets, $50 \mathrm{~cm}$ in diameter, either 60 or $80 \mu \mathrm{m}$ mesh size, from $80-0 \mathrm{~m}$ depth.

Material was preserved in $2 \%-4 \%$ formaldehyde. Specimens belonging to Thalia democratica forma indopacifica Van Soest, 1975, T. cicar, T. orientalis, T. rhomboides, and $T$. sibogae were studied; $T$. rhinoceros was not found. In the solitary zooids the length from the oral to atrial opening (LT) and the stolon length (LST) were measured. Stolon bud number and block number were recorded as well as total fiber number
(FTOT) and muscle III (MIII) fiber number. The stolon length was obtained by drawing the stolon using a camera lucida and then measuring by a Kontron Bildanalyse Minimop. Nonparametric correlations were calculated with the Kendall rank correlation test (Daniel, 1978) between buds number in Block I (BI), buds number in Block II (BII), total fiber number (FTOT), fiber number in muscie III (MIII), total length (LT), stolon length (LST), and species (SP). A Kruskal and Wallis analysis and a multiple comparison Dunn test were performed as well (Daniel, loc. cit). Nonparametric tests were chosen because the data did not show a normal distribution.

For comparison, Thalia longicauda specimens obtained at two stations in the southwestern Atlantic Ocean $\left(36^{\circ} 56^{\prime} \mathrm{S}\right.$ $53^{\circ} 27^{\prime} \mathrm{W}$ and $39^{\circ} 48^{\prime} \mathrm{S} 54^{\circ} 13^{\prime} \mathrm{W}$ ) were used.

\section{Results}

\section{Stolon features}

The main aspects of stolon arrangement are similar in solitary zooids of all species of the "Thalia democratica group". The present description corresponds to $T$. sibogae, one of the least known species of the group, having the most restricted distribution (Indo-Pacific). It was described by Van Soest (1973) from a very rich sample from the type locality $\left(05^{\circ} \mathrm{N} 120^{\circ} \mathrm{E}\right)$ and a specimen captured in the Philippine Archipelago by the Albatross Expedition (1908). The only more recent record (Esnal et al., 1993) is from the same area and provides the material used in the present study.

In the youngest specimens a cell accumulation is observed in the midventral line in the region between the posterior part of the endostyle and the anterior part of the "nucleus" (tightly looped gut) (Fig. 1). These cells proliferate and give rise to a tube, the stolon, which extends and wraps itself around the "nucleus" and strobilates. It could be observed that the stolon begins segmentation (growing zone) by forming a simple row of buds at first and a double one later (Figs. 2A-C).

The completely developed stolon (Fig. 2B) presents two blocks of buds beginning from the deployment point (the point where the stolon passes from a single to a double row of buds). This trait is shared with the species of the genus Salpa (cf. Foxton, 1966). Between the proximal block (BI) and the distal one (BII) no "intermediate piece" region is observed. This is a zone characterized by 


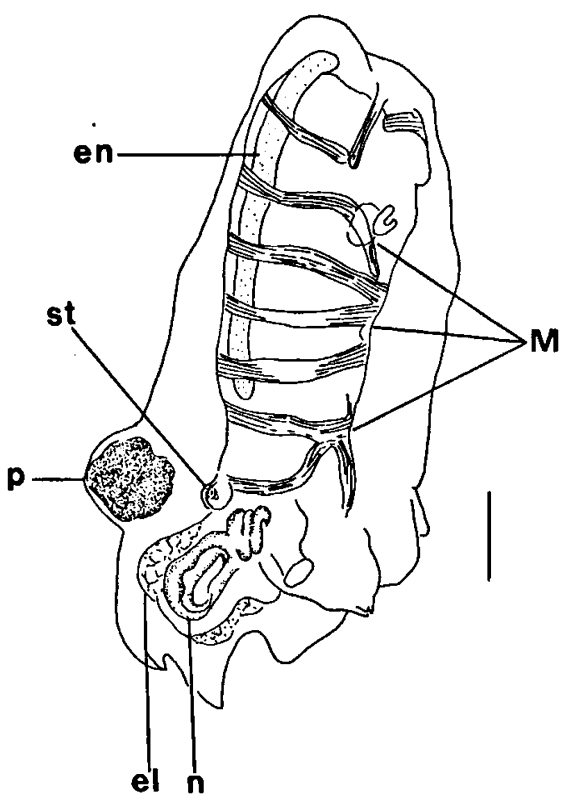

Fig. 1. Thalia sibogae Van Soest, 1973, lateral view of embryo (el = eleoblast; $\mathrm{en}=$ endostyle; $\mathrm{M}=$ muscles; $\mathrm{n}$ = "nucleus"; $\mathrm{p}=$ placenta; $\mathrm{st}=$ stolon). Scale $=0.2 \mathrm{~mm}$.

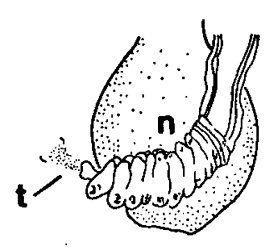

A
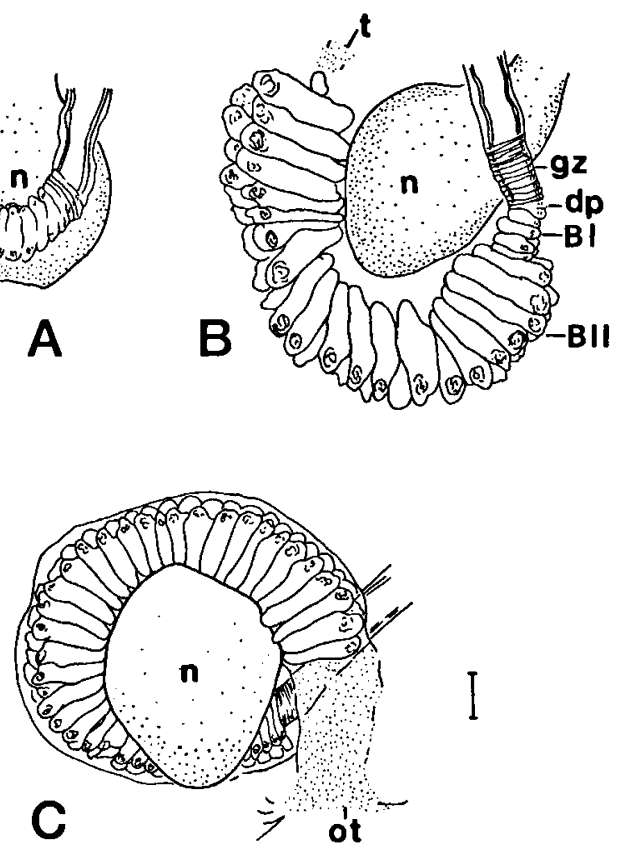

Fig. 2. Thalia sibogae Van Soest, 1973, detail of the "nucleus" region showing stolon development: $A$, initial strobilation and tunnel formation; B, stolon wrapping around the "nucleus"; C, one block has been liberated, the tunnel remains open; $\mathrm{BI}=$ block I; BII = block II (distal block); dp = deployment point; gz = growing zone; $r=$ "nucleus"; ot = open tunnel; $t=$ starting tunnel. Scale $=0.2 \mathrm{~mm}$.

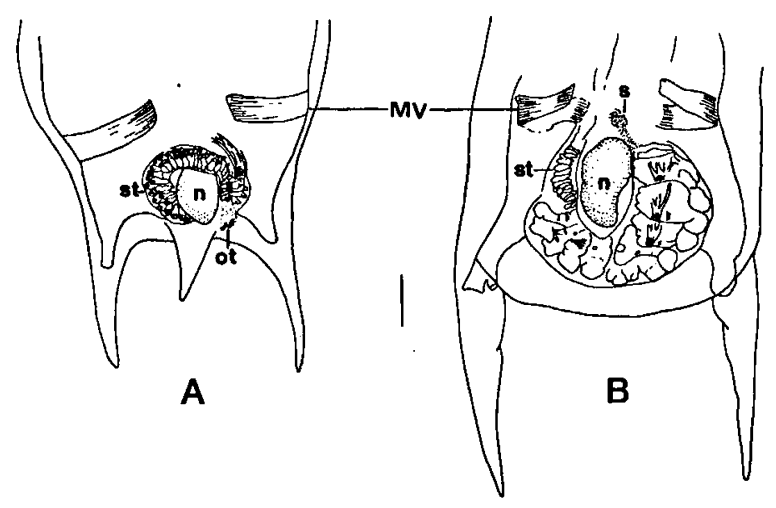

Fig. 3. Posteroventral body region of solitary zooids: A, Thalia sibogae; $\mathrm{B}$, T. longicauda $(\mathrm{MV}=$ muscle V; $\mathrm{n}=$ "nucleus"; ot = open tunnel; s = scar showing tunnel closure; st = stolon). Scale $=0.5 \mathrm{~mm}$.

the presence of abortive buds that mark the boundary between a block of buds and the next, in species belonging to the genera Salpa and Iasis (cf. Johnson, 1910; Foxton, 1966; Esnal et al., 1987).

When the distal block of the stolon is completed it emerges through a tunnel excavated in the ventral region of the test that opens lateral and posterior to the "nucleus" (Fig. 3A). The tunnel seems to be formed before the exit of the block. It may be observed in Figs. 2A and B that the region which is desintegrating and forming the tunnel is placed in front of the developing stolon. Fig. 2C shows a specimen that has already liberated one block, while the tunnel remains open.

In Thalia longicauda the stolon arrangement is similar, but the opening is located in the mid ventral region anterior to the "nucleus" (Fig. 3B).

In Salpa and Iasis, once a block has been released, the opening in the test is closed leaving a scar (Foxton, 1966; Esnal et al., 1987). Also in Thalia longicauda, specimens were found with two totally formed blocks and a scar, showing that at least one block had already been liberated, thus the number of blocks produced would be no less than 3 (Fig. 3B). In the studied species of the "Thalia democratica group", on the contrary, no specimens were found with clear evidence of a scar. In most of the specimens having two blocks, the last block was coming out or was nearly to doing so (Figs. $2 \mathrm{C}$ and $3 \mathrm{~A}$ ). Thus it is only possible to be sure that at least two blocks of blastozooids are formed. 


\section{Biometric results}

The results of the correlation study between the variables considered are shown in Table I. Three correlations were observed that were expected based on the relationships among the variables: FTOT (total number of muscle fibers) and MIII (number of fibers of muscle III) and stolon length (LST) with bud number in BI and BII. Besides, total length (LT) correlates with stolon length (LST). As a consequence of the correlation between $\mathrm{BI}$ and BII with LST and of LST with LT, the number of buds in BI and BII is also correlated with LT. Thus, as was found for Iasis zonaria (cf. Esnal et al., 1987), the number of buds per block seems to be a good indicator of the growth rate of the solitary zooid. A lower and negative correlation appears between BII and fiber number. Both LST and LT are correlated with the species considered, consequently this relationship was studied with a different technique.

The level of significance of the differences between the means of the different variables was studied by means of the nonparametric Kruskal-
Wallis test (cf. Daniel, 1978). The results presented in Table II show that for all variables, number of buds in BI excepted, the five species belong to different statistical populations.

Multiple comparison analysis using the Dunn test (Daniel, loc. cit.) shows separation of the species compared (Table III): Thalia democratica, $T$. rhomboides, and T. orientalis are discriminated by FTOT and MIII. In addition BII separates $T$. orientalis from $T$. democratica. Thalia sibogae is separated from the remaining species by FTOT, MIII, and LT, being also distinguishable from $T$. democratica on account of stolon length. Thalia cicar diverges from $T$. rhomboides on account of MIII and FTOT but is not separable from $T$. democratica and $T$. orientalis.

\section{Embryo development}

It was observed in all species that only one embryo per blastozooid is formed. Its development is similar to the one described by Brooks (1876), Brien (1928), and Berrill (1950) for T. democratica.

Table I. Correlation study among measured variables of Thalia species (Kendall rank correlations). The correlation coefficient and significance level of each coefficient are indicated. The sample size is 202 specimens in all cases. BI = number of buds in block $\mathrm{I}$; BII = number of buds in block II; FTOT = total fibers number; MIII = number of fibers in muscle III; LOT = total length (from oral to atrial openings); LST = total stolon length; $\mathrm{SP}=$ species.

\begin{tabular}{lrrrrrrr}
\hline & BI & BII & FTOT & MIII & LOT & LST & SP \\
\hline BI & 1.0000 & .0903 & -.1084 & -.1175 & .4135 & .4797 & .1030 \\
& 1.0000 & .1212 & .0346 & .0256 & .0000 & .0000 & .0639 \\
BII & .0903 & 1.0000 & -.1831 & -.1895 & .2398 & .4597 & .1798 \\
& .1212 & 1.0000 & .0011 & .0010 & .0000 & .0000 & .0032 \\
& & & & & & & \\
FTOT & -.1084 & -.1831 & 1.0000 & .8800 & .0850 & -.0494 & .0115 \\
& .0346 & .0011 & 1.0000 & .0000 & .0821 & .3095 & .8297 \\
MIII & -.1175 & -.1895 & .8880 & 1.0000 & .0820 & -.0582 & .0086 \\
& .0256 & .0010 & .0000 & 1.0000 & .1024 & .2426 & .8767 \\
& & & & & & & \\
LOT & .4135 & .2398 & .0850 & .0820 & 1.0000 & .5857 & .3341 \\
& .0000 & .0000 & .0821 & .1024 & 1.0000 & .0000 & .0000 \\
& & & & & & & \\
LST & .4797 & .4597 & -.0494 & -.0582 & .5857 & 1.0000 & .2045 \\
& .0000 & .0000 & .3095 & .2426 & .0000 & 1.0000 & .0001 \\
SP & .1030 & .1798 & .0115 & .0086 & .3341 & .2045 & 1.0000 \\
& .0639 & .0032 & .8297 & .8767 & .0000 & .0001 & 1.0000 \\
\hline
\end{tabular}


Table II. Kruskall-Wallis analysis of variance in all species (cf. Daniel, 1978), BI = number of buds in block I; BII = number of buds in block II; FTOT = total fibers number; MIII = number of fibers in muscle III; LT = total length (from oral to atrial openings); LST = total stolon length; $N=$ sample size; $P=$ probability of all species pertaining to the same statistical population.

\begin{tabular}{lccccrrr}
\hline Species & $N$ & mean BI & mean BII & mean FTOT & mean MIII & mean LT & mean LST \\
\hline$T$. democratica & 61 & 90.02 & 85.16 & 98.73 & 97.93 & 75.52 & 81.61 \\
$T$. rhomboides & 28 & 94.64 & 96.45 & 171.27 & 174.29 & 101.73 & 91.14 \\
$T$. orientalis & 54 & 110.41 & 118.86 & 46.79 & 47.25 & 94.02 & 106.71 \\
$T$. cicar & 10 & 127.90 & 116.00 & 54.70 & 57.05 & 83.95 & 117.75 \\
$T$. sibogae & 49 & 104.50 & 112.64 & 134.93 & 133.20 & 149.26 & 123.11 \\
Test statistics & & 6.54 & 20.25 & 110.62 & 112.10 & 49.54 & 15.84 \\
$P$ & & $1.610^{-2}$ & $4.410^{-4}$ & $<10^{-10}$ & $<10^{-10}$ & $4.510^{-10}$ & $3.210^{-3}$ \\
\hline
\end{tabular}

Table III. Study of the significance of differences in multiple comparisons by the Dunn test (cf. Daniel, 1978). BI = number of buds in block I; BII = number of buds in block II; FTOT = total fibers number; MIII = number of fibers in muscle III; LT = total length (from oral to atrial openings); LST $=$ total stolon length; ${ }^{* *}=$ significant at $\alpha=0.2$.

\begin{tabular}{|c|c|c|c|c|c|c|}
\hline Comparisons & BI & BII & FTOT & MIII & LT & LST \\
\hline$T$. democratica vs. $T$. rhomboides & -4.62 & -11.29 & $-72.54 * *$ & $-76.35^{* *}$ & -29.21 & -9.53 \\
\hline T. democratica vs. $T$. orientalis & -20.38 & $-33.71 * *$ & $51.94^{* *}$ & $50.68 * *$ & -21.49 & -25.10 \\
\hline T. democratica vs. $T$. cicar & -37.88 & -30.84 & 44.03 & 40.88 & -11.43 & -36.14 \\
\hline T. democratica vs. $T$. sibogae & -14.48 & -17.49 & $-36.20 * *$ & $-35.27 * *$ & $-76.74^{* *}$ & $-41.50^{* *}$ \\
\hline T. rhomboides vs. $T$. orientalis & -15.76 & -22.42 & $124.48^{* *}$ & $127.04^{* *}$ & 7.71 & -15.57 \\
\hline T. rhomboides vs. $T$. cicar & -33.28 & -19.55 & $116.57 * *$ & $117.24 * *$ & 17.78 & -26.61 \\
\hline T. rhomboides vs. T. sibogae & -9.86 & -6.20 & $36.34 * *$ & $41.08 * *$ & $-47.53 * *$ & -31.97 \\
\hline$T$. orientalis vs. $T$. cicar & -17.49 & 2.86 & -7.91 & -9.80 & 10.07 & -11.04 \\
\hline T. orientalis vs. T. sibogae & 5.91 & 16.22 & $-88.14^{* *}$ & $-85.95^{* *}$ & $-55.25^{* *}$ & -16.40 \\
\hline T. cicar vs. $T$. sibogae & 23.40 & 13.36 & $-80.23^{* *}$ & $-76.15^{* *}$ & $-65.32 * *$ & -5.36 \\
\hline
\end{tabular}

In $T$. longicauda the solitary zooid reaches a large size within the body of the aggregate zooid before its liberation. Furthermore, the stolon starts segmentation before the liberation is realized. This fact has also been noticed by Godeaux (1967).

\section{Sympatric occurrence of taxa}

In Figs. 4 and 5 the frequency of occurrence of each of these taxa and the frequency of simultaneous occurrence of two, three, or four of them in the EASTROPAC and MORO expeditions are shown. The frequency of simultaneous occurrence of two or more taxa was $38 \%$ in the EASTROPAC and $22.2 \%$ in the MORO expedition. In the former case the samples were taken by conventional, oblique hauls from $200 \mathrm{~m}$ to the surface with nets without closing devices. Although it is not very likely, because salps in general live in the euphotic zone, it is conceivable that specimens were captured that came from different specific populations living in different vertical strata. In that case the taxa present in the same sample would not be truly sympatric. However, samples from the MORO expedition came from shallow waters, since they were taken from a launched skiff.

\section{Discussion}

The position of the opening through which the bud blocks are liberated to the outside permits to differentiate the solitary zooid of Thalia longicauda from the rest of the species belonging to the "Thalia democratica group", which would be another element to corroborate the opinion of Godeaux (1967) and Van Soest (1973) that this is a species clearly separated from the others.

On the contrary, in the species of the "Thalia 


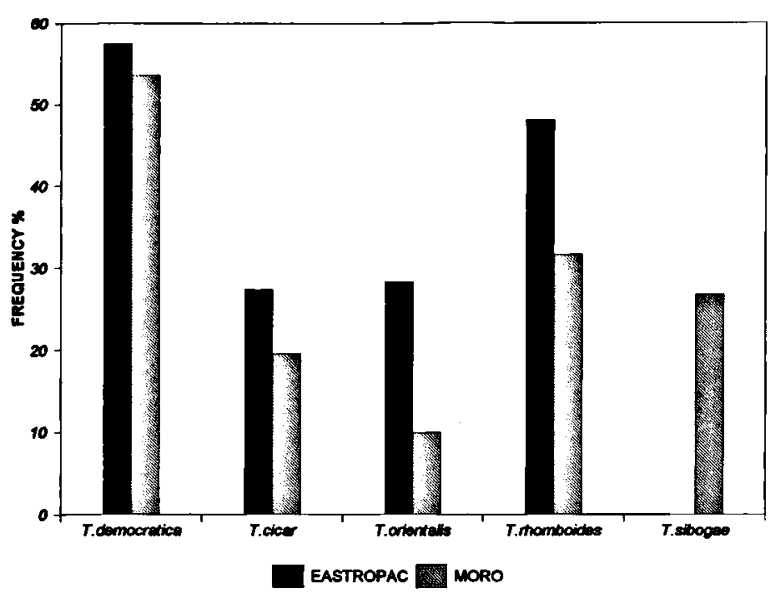

Fig. 4. Species frequency in percent of the "Thalia democratica group" during the EASTROPAC (black bars) and MORO (grey bars) expeditions.

democratica group" no gross morphological differences in stolon arrangement are evident among species. On the other hand, the morphometric features of the stolon only permit to differentiate the solitary zooids of $T$. sibogae from $T$. democratica. Other variables such as the number of muscular fibres do permit to establish differences between most of them through the Dunn test (Daniel, 1978). If other features such as the shape of the atrial palps and presence of projections and echinations are considered as well, the separation becomes clear, as was established by Van Soest (1973) and Dauby \& Godeaux (1987).

Embryo development does not permit a differentiation between species.

As Van Soest (1973) expressed, the taxonomic status of these forms, which he presented as species, remains a matter of consideration. The fact that they occur sympatrically is in favour of species status. On many occasions during this study the species appeared in the same plankton sample and no "hybrids" or intermediates were found. Likewise, Van Soest (1975b) found a high frequency of simultaneous occurrences of two, three, and four of these taxa. He even mentions that $T$. democratica and $T$. cicar, in the southern Caribbean, were found in the same sample in high numbers indicating swarm-like conditions for both species simultaneously without interbreeding. The

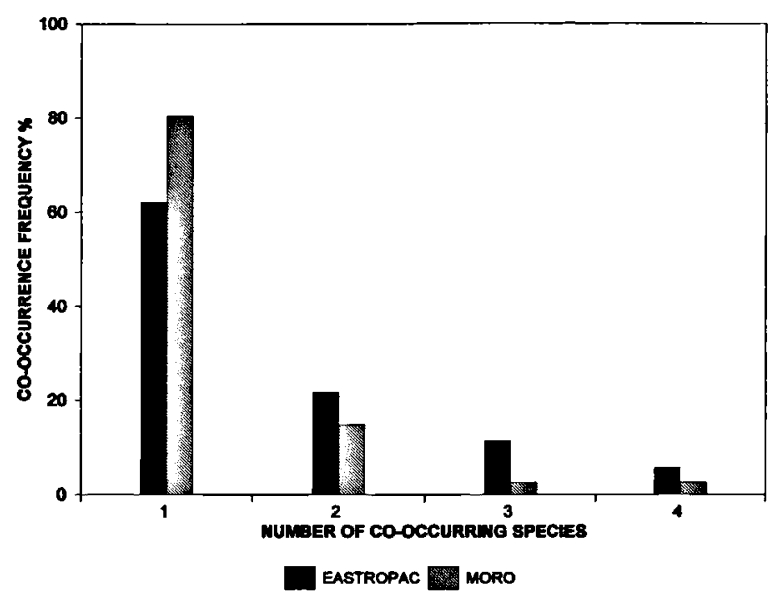

Fig. 5. Frequency of occurrence of one, two or more species of the "Thalia democratica group" simultaneously in the EASTROPAC (black bars) and MORO (grey bars) expeditions.

same was observed by Esnal (1979) in the Gulf of Mexico and the Caribbean Sea, where T. orientalis also occurred next to $T$. democratica and $T$. cicar. However, Van Soest (1975b) did not reject the possibility that this might be a case of genetic polymorphism, but so far there is no proof for this.

\section{Acknowledgements}

We are grateful to Dr. Frank Ferrari of the Smithsonian Oceanographic Sorting Center, Washington, who kindly provided the material and supplementary information about the EASTROPAC and MORO expeditions. This research was supported by grants from CONICET and UBACYT to G.B.E.

\section{References}

Berrill, N.J., 1950. Budding and development in Salpa. J. Morph., 87: 553-606.

Borgelt, J.P., 1968a. The subspecific differentiation of the salp Thalia democratica (Forskål, 1775) based on numerical taxonomical studies. Trans. roy. Soc. S. Afr., 38: 4564.

Borgelt, J.P., 1968b. A new subspecies of the salp Thalia democratica (Forskål, 1775) and a revised description of Thalia democratica var. orientalis Tokioka. Trans. roy. Soc. S. Afr., 38: 65-76.

Braconnot, J.C., 1973. Contribution à l'étude des stades successifs dans le cycle des Tuniciers pélagiques Salpides en Méditerranée. Bull. Inst. océanogr. Monaco, 71(1424): 1-27. 
Brien, P., 1928. Contribution à l'étude de l'embryogenèse et de la blastogenèse des Salpes. Recueil Inst. zool. TorleyRousseau, 2: 5-116.

Brooks, W.K., 1876. On the development of Salpa. Bull. Mus. comp. Zool., 3(14): 291-348.

Daponte, M.C. \& G.B. Esnal, 1994. Differences in embryological development in two closely related species Ihlea racovitzai and Ihlea magalhanica (Tunicata, Thaliacea). Polar Biol., 14: 455-458.

Daniel, W.W., 1978. Nonparametric statistics: 1-502 (Houghton Mifflin Co., Boston).

Dauby, P. \& J. Godeaux, 1987. Application de l'analyse multidimensionelle aux espèces du genre Thalia (Tunicata: Thaliacea). Annls. Soc. r. zool. Belg., 117: 175-180.

Esnal, G.B., 1979. Los sálpidos (Tunicata, Thaliacea) del Golfo de México y Mar Caribe. Physis (Buenos Aires), (Secc. A), 38(94): 59-66.

Esnal, G.B. \& M.C. Daponte, 1990. Stolon development and some aspects of musculature in the characterization of Ihlea racovitzai (van Beneden, 1913) and Ihlea magalhanica (Apstein, 1894) (Tunicata, Thaliacea). Polar Biol., 10: 265-268.

Esnal, G.B., M.C. Daponte, B.E. Casareto \& R.J. Castro, 1987. Iasis zonaria (Pallas, 1774) (Tunicata, Thaliacea) de las costas argentinas. Reproducción y distribución. Physis (Buenos Aires), (Secc. A), 45(109): 69-77.

Esnal, G.B., M.C. Daponte \& L.C. Simone, 1993. Pelagic tunicates (Appendicularia and Thaliacea) from the Tropical Western Pacific Ocean. Physis (Buenos Aires), (Secc. A), 48(114):41-48.

Foxton, P., 1966. The distribution and life-story of Salpa thompsoni Foxton with observations on a related species, Salpa gerlachei Foxton. Disc. Rep., 34: 1-116.

Godeaux, J., 1967. Une salpe peu connue, Thalia longicauda Quoy et Gaimard. Annls. Soc. roy. zool. Belg., 97(2): 91102.

Johnson, M.E., 1910. A quantitative study of the development of the Salpa chain in Salpa fusiformis-runcinata. Univ. Calif. Publs. Zool., 6(7): 145-176.

Soest, R.W.M. van, 1973. The genus Thalia Blumenbach, 1798 (Tunicata, Thaliacea), with descriptions of two new species. Beaufortia, 20(271): 193-212.

Soest, R.W.M. van, 1975a. Observations on taxonomy and distribution of some salps (Tunicata, Thaliacea), with descriptions of three new species. Beaufortia, 23(302): 105129.

Soest, R.W.M. van, 1975b. Zoogeography and speciation in the Salpidae (Tunicata, Thaliacea). Beaufortia, 23(307): 181-215.

Tokioka, T., 1937. Notes on salps and doliolums occurring on the Pacific coasts of Middle Japan. Annot. zool. Japon., 16(3): 219-235.

Received: 2 January 1996 